\title{
Prototype Sistem Multi-Telemetri Wireless Untuk Mengukur Suhu Udara Berbasis Mikrokontroler ESP8266 Pada Greenhouse
}

\author{
Hanum Shirotu Nida ${ }^{*}$, Mahar Faiqurahman ${ }^{2}$, Zamah Sari ${ }^{3}$ \\ 1,2,3 Universitas Muhammadiyah Malang \\ hanumshirotunida@outlook.com*1, mahar@umm.ac.id², abdzamahsari@gmail.com³
}

\begin{abstract}
Abstrak
Telemetri wireless adalah proses pengukuran parameter suatu obyek yang hasil pengukurannya dikirimkan ke tempat lain melalui proses pengiriman data tanpa menggunakan kabel (wireless), sedangkan multi telemetri adalah gabungan dari beberapa telemetri itu sendiri. Penelitian ini merancang prototype sistem multi-telemetri wireless untuk mengukur suhu udara dan kelembaban udara pada greenhouse dengan menggunakan sensor DHT11 dan data hasil dari pembacaan sensor dikirim dengan menggunakan modul WiFi ESP8266 ke server dengan menggunakan protokol HTTP. Dalam penelitian ini diuji nilai sensor DHT11, heap memory ESP8266, jarak atau jangkauan ESP8266, uji coba data missing handling dan kestabilan jaringan. Berdasarkan hasil pengujian diketahui bahwa sensor DHT11 memiliki rata-rata kesalahan ukur suhu $0.92{ }^{\circ} \mathrm{C}$ dan kelembaban 3.1\%. Modul WiFi ESP8266 mampu menyimpan dan mengirim buffer hingga 100 data dan dapat melakukan pengiriman dalam jangkauan 50 meter. Data missing handling memanfaatkan buffer untuk menyimpan data selama server sedang tidak dapat diakses oleh sensor node agar data tidak hilang. Kestabilan pengiriman data atau koneksi sensor node dengan server dipengaruhi oleh jumlah access point yang sedang berkomunikasi di sekitar access point server dengan menggunakan channel yang sama.
\end{abstract}

Kata kunci: Telemetri, Wireless, ESP8266, DHT11, Greenhouse

\begin{abstract}
Wireless telemetry is a process of measuring an object parameter, the measurement results sent to another node through the process of sending data wireless, whereas multi telemetry is a composite of several telemetry itself. In this study is designed prototpye multitelemetry systems to measure air temperature and humidity in greenhouse using DHT11 sensors and outcome data from sensor readings are sent using the WiFi module ESP8266 to the server using HTTP protocol. In this study tested the sensor value of DHT11, heap memory of ESP8266, ESP8266 distance or range, data missing handling test and network stability. Based on test results DHT11 known that the sensor has an average error of measuring temperature is $0.92{ }^{\circ} \mathrm{C}$ and humidity is 3.1\%. ESP8266 WiFi module is able to store and transmit buffers up to 100 data and can make deliveries within a range of 50 meters. Also, data missing handling utilizing a buffer to store data during unavailable server observer is not accessible by the sensor nodes to reduce the risk of data loss. The stability data or sensor connection to the server node is affected by the number of access points are communicating around the access point server by using the same channel.
\end{abstract}

Keywords: Telemetri, Wireless, ESP8266, DHT11, Greenhouse

\section{Pendahuluan}

Greenhouse atau yang biasa disebut rumah kaca adalah sebuah bangunan yang terdiri dari bahan kaca atau plastik yang tebal dan menutup seluruh permukaan baik dinding maupun atap. Model bangunan greenhouse ini banyak digunakan untuk kegiatan pertanian yang tidak tergantung pada keadaan musim dan dapat dilakukan sepanjang tahun. Tumbuhan yang dibudidayakan pun dapat bervariasi. Sehingga menentukan karakteristik kondisi lingkungan greenhouse yang harus dipenuhi oleh petani. Beberapa parameter yang digunakan sebagai acuan menentukan kondisi lingkungan dari greenhouse, untuk tanaman tertentu diantaranya adalah kondisi suhu, kelembaban udara, pencahayaan, kadar $\mathrm{CO}_{2}$, dan sebagainya [1]. 
Berbagai teknologi telah dikembangkan untuk memantau kondisi dari greenhouse. Proses pemantauan ini bertujuan untuk menganalisis segala perubahan kondisi lingkungan pada greenhouse. Salah teknologi yang digunakan adalah sistem monitoring dengan memanfaatkan sensor. Beberapa penelitian sebelumnya telah memanfaatkan sistem sensor untuk melakukan monitoring, seperti pada sistem monitoring listrik prabayar [2], sistem monitoring air nutrisi akuaponik [3], dan sistem monitoring healthcare yang dipasang pada tubuh [4]. Sedangkan penerapan sistem monitoring pada greenhouse telah dilakukan pada beberapa penelitian sebelumnya [5] [6] [7]. Pada penelitian tersebut, di dalam arsitektur sistem monitoring yang dibangun, juga memanfaatkan sensor sebagai instrumen untuk mengambil data dari lingkungan. Data hasil sensing tersebut dikirim oleh sensor node ke server dengan memanfaatkan jaringan wireless. Hal ini dilakukan dengan pertimbangan karena lokasi dari sensor node cukup jauh dari server pengolah data, sehingga penggunaan medium wireless dapat meningkatkan efisiensi komunikasi. Jika jumlah sensor node yang dipasang pada greenhouse tersebut cukup banyak maka sistem tersebut dapat membentuk wireless sensor network.

Berkaitan dengan arsitektur wireless sensor network terdapat konsep telemetri. Telemetri adalah proses pengukuran parameter suatu obyek (benda ruang, kondisi alam) yang hasil pengukurannya dikirimkan ke tempat lain melalui proses pengiriman data baik dengan menggunakan kabel maupun tanpa kabel (wireless) [8][9]. Multi-telemetri wireless merupakan gabungan dari beberapa telemetri yang hasilnya dikirim ke tempat lain menggunakan jaringan nirkabel. Multi-telemetri wireless diangkat dari teknologi wireless sensor network (WSN), yaitu suatu jaringan nirkabel yang terdiri dari kumpulan sensor node yang tersebar di suatu area tertentu (sensor field).

Penelitian yang telah dilakukan tentang pengembangan sistem telemetri wireless dilakukan pada "Perancangan Sistem Telemetri Wireless untuk Mengukur Suhu dan Kelembaban Berbasis Arduino Uno R3 ATmega328P dan Xbee Pro" [10]. Pada penelitian ini proses pengiriman data menggunakan modul Xbee Pro sebagai modul komunikasi dan Arduino Uno R3 ATmega328P sebagai sensor node yang menghubungkan modul WiFi dengan sensor. Pada penelitian yang telah dilakukan, ini penggunaan komponen Xbee Pro dirasa cukup mahal, apalagi untuk pengembangan sistem telemetri yang skalabilitasnya sangat tinggi dan membutuhkan sensor node yang cukup banyak.

Berdasarkan pembahasan dari penelitian sebelumnya, penelitian ini dikembangkan prototype sistem multi-telemetri wireless untuk mengukur suhu udara pada greenhouse dengan menggunakan sensor suhu DHT11 dan modul WiFi ESP8266 sebagai sensor node yang diimplementasikan pada greenhouse. Modul WiFi ESP8266 dipilih dalam penelitian ini karena memiliki kelebihan yaitu biaya yang jauh lebih rendah dibandingkan Xbee Pro dan dapat digunakan langsung untuk membaca data sensor tanpa menggunakan perangkat Arduino sehingga dapat menghemat konsumsi energi. Dalam penelitian ini juga dilakukan pengukuran kinerja ESP8266 apakah modul tersebut dapat berfungsi dengan baik ketika melakukan proses sensing dan pengiriman data. Sensor suhu akan dipasang di dalam beberapa greenhouse dan data yang dibaca oleh sensor kemudian dikirimkan ke server dengan menggunakan modul WiFi ESP8266 yang tersambung dengan sensor. Server menerima data yang dikirimkan oleh modul WiFi dan menyimpannya ke dalam database kemudian menampilkan data dalam bentuk website.

\section{Metode Penelitian}

Pada penelitian ini, sistem multi-telemetri digunakan untuk memantau suhu udara pada prototype greenhouse yang dapat dilakukan dari tempat yang berbeda. Sistem ini dapat memantau beberapa greenhouse sekaligus sehingga dapat mempermudah proses pemantauan. Pada sistem yang dibangun ini, proses pengambilan data suhu dan kelembaban udara digunakan sensor DHT11. Sedangkan untuk proses pengiriman data hasil sensor, digunakan modul WiFi ESP8266. Data hasil pembacaan sensor dikirim dari sensor node ke server dengan menggunakan protokol HTTP, selanjutnya data hasil pengiriman tersebut akan ditampilkan dalam bentuk aplikasi web.

Dalam penelitian ini juga dilakukan pengukuran kinerja dari modul WiFi ESP8266 yang digunakan sebagai media untuk mengirimkan data secara wireless, sekaligus sebagai sensor node yang melakukan pembacaan hasil proses sensing oleh sensor. Pengujian dilakukan pada beberapa hal meliputi analisis heap memory, pengaruh jangkauan atau jarak pengiriman ESP8266 terhadap keberhasilan pengiriman data, data missing handling ketika server tidak dapat diakses oleh sensor node baik karena jaringan yang tidak stabil maupun ketika server sedang 
off, serta pengujian kestabilan jaringan. Selain itu pada penelitian ini juga dilakukan kalibrasi dengan membandingkan hasil data sensor DHT11 dengan alat pengukur suhu HTC-1.

Dalam skenario arsitektur sistem yang dibuat, terdapat tiga greenhouse yang masingmasing dipasang sensor suhu dan kelembaban udara menggunakan sensor DHT11 yang terhubung dengan modul WiFi ESP8266. Komponen utama yang terdapat pada arsitektur sistem, yaitu:

1. Sensor node

Sensor node terdiri dari sensor suhu dan kelembaban DHT11 dan modul WiFi ESP8266 sebagai media komunikasinya. Sensor node mengirim data hasil sensing dalam bentuk HTTP request ke server melalui protokol HTTP.

2. Access point

Access point digunakan sebagai perantara komunikasi antara sensor node dan server. Dalam skenario system digunakan access point agar server dapat terkoneksi ke beberapa sensor node sekaligus.

3. Server

Server berfungsi untuk menerima dan mengolah data dari hasil sensing dari sensor node melalui protokol HTTP. Setelah berhasil menerima data sensor dari sensor node, server akan mengirimkan HTTP respons ke sensor node, sebagai pemberitahuan bahwa proses pengiriman telah berhasil.

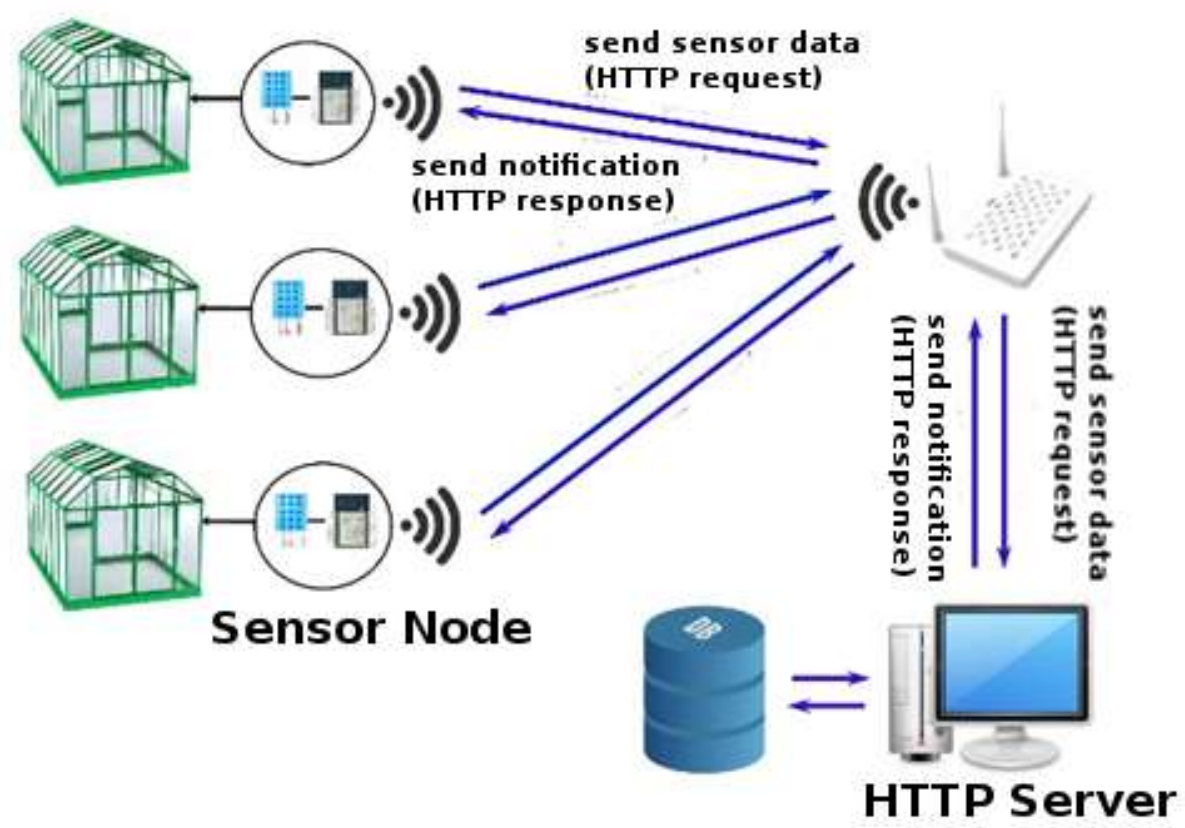

Gambar 1. Arsitektur Sistem

Gambar 1 menunjukkan arsitektur sistem yang diimplementasikan dalam penelitian ini. Modul WiFi ESP8266 yang juga sekaligus berperan sebagai sensor node, melakukan pembacaan nilai sensor DHT11, dan kemudian mengirimkan data hasil sensing tersebut melalui HTTP request ke komputer server dengan perantara access point. Setelah itu data akan dimasukkan ke dalam database yang terdapat pada HTTP server. HTTP server mengirimkan HTTP respons kembali ke sensor node sebagai pemberitahuan bahwa HTTP server tersebut menerima data sensor. Ketika sensor node menerima HTTP respons dari server, maka sensor node akan melakukan proses sensing kembali dan kemudian mengirimkan hasilnya melalui HTTP request ke server. Proses tersebut akan diulang selama proses sensing berlangsung.

Dalam arsitektur yang dibangun, diimplementasikan mekanisme data missing handling yaitu suatu mekanisme pada sensor node yang digunakan untuk mengatasi hilangnya data ketika server tidak bisa diakses oleh sensor node. Proses ini dilakukan dengan memanfaatkan memori di sensor node sebagai buffer dalam pengiriman data. Buffer adalah area memory di dalam ESP8266 yang digunakan untuk menyimpan data ketika data sedang dipindahkan antara dua titik, yaitu antara sensor node dengan server. 


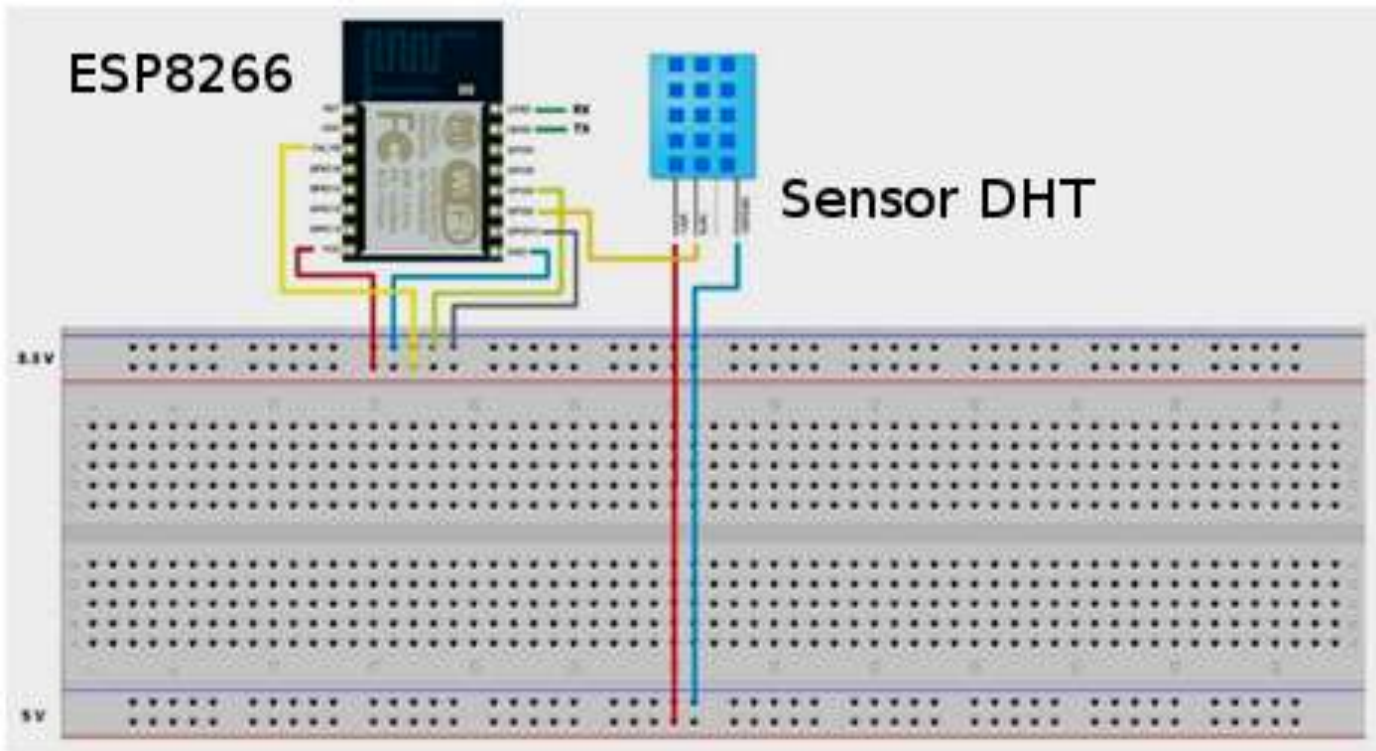

Gambar 2. Rangkaian Sensor Node

Gambar 2 merupakan rangkaian dari sensor node terdiri dari modul WiFi ESP8266 dan sensor suhu DHT11 yang diberi tegangan 3.3 Volt dan 5 Volt. Sensor DHT11 akan melakukan pembacaan suhu di dalam greenhouse secara berkala. Data dari sensor DHT11 kemudian dibaca oleh ESP8266 melalui Pin GPIO02. Setelah proses pembacaan data dari sensor DHT11 dilakukan, ESP8266 akan menyimpan data hasil sensing tersebut ke array buffer yang terdapat di dalam memori ESP8266. Secara periodik juga data hasil sensing yang ada di dalam buffer tersebut akan dikirimkan ke server melalui jaringan WiFi.

Gambar 3 merupakan diagram alur dari proses yang terdapat pada sensor node dan server. Setelah sensor node aktif maka sistem akan mencoba terhubung ke jaringan yang tersedia. Setelah itu sensor node melakukan proses inisialisasi array yang digunakan untuk mekanisme buffer pada memori. Sensor node melakukan proses sensing yang hasilnya disimpan dalam buffer yang sudah diinisialisasi. Besarnya total data sensor yang disimpan ini dalam buffer array tersebut tergantung dari besar buffer array yang sudah diinisialisasi sebelumnya. Setelah isi buffer penuh, maka sensor node akan mengirimkan data hasil sensing ke server, dengan terlebih dahulu mengubah data ke dalam format JSON. Proses pengiriman data dilakukan dengan menggunakan HTTP request. Jika pengiriman berhasil, maka sensor node akan menerima HTTP respons dari server. Selanjutnya isi dari buffer array yang terdapat di dalam sensor node akan dikosongkan agar dapat digunakan untuk menyimpan kembali data hasil sensing berikutnya. Jjika pengiriman gagal (sensor node tidak menerima HTTP respons dari server), maka sensor node akan mencoba mengirim ulang data hasil sensor sampai beberapa kali. Sementara data hasil sensor akan tetap disimpan dalam buffer array. Proses yang dilakukan ini merupakan mekanisme data missing handling yang diterapkan dalam sensor node. Jika selama beberapa kali proses pengiriman (dengan HTTP request) gagal, maka sensor node akan mengosongkan isi buffer array, dan memulai kembali proses sensing untuk mengambil data yang terbaru.

Ketika server aktif, maka server akan selalu berada pada kondisi listening untuk menunggu pengiriman data hasil sensing dari sensor node dalam bentuk HTTP request. Jika server dapat menerima HTTP request dari sensor node, maka server akan langsung mengirimkan HTTP respons ke sensor node, sebagai pemberitahuan bahwa server sudah menerima data hasil sensing dari sensor node. Untuk selanjutnya server melakukan parsing pada HTTP request untuk mengambil data hasil sensing dalam bentuk JSON. Kemudian data hasil parsing tersebut disimpan ke dalam database, untuk ditampilkan ke dalam web monitoring. 


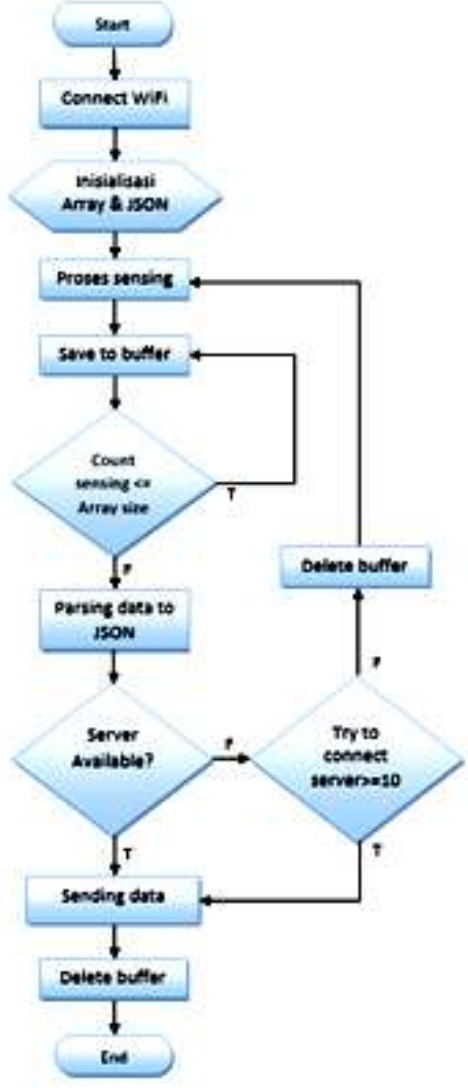

Diagram alur pada sensor node

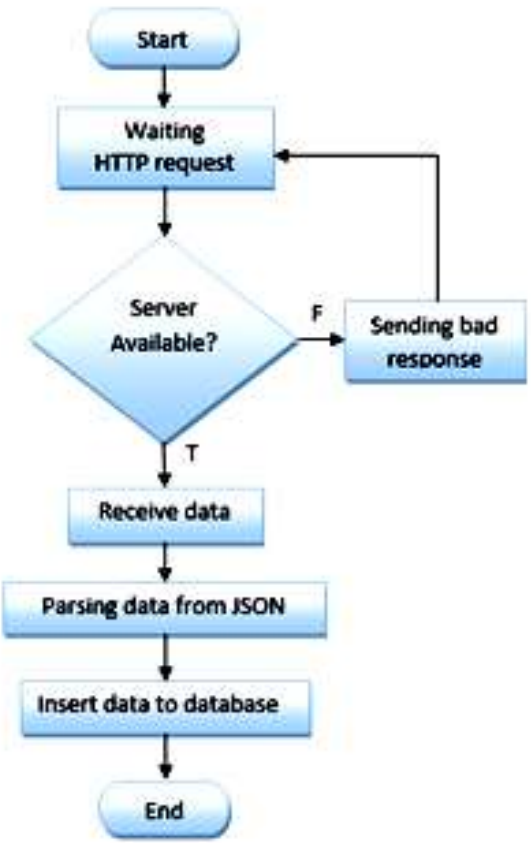

Diagram alur pada server

Gambar 3. Diagram Alur Pada Sensor Node dan Server

\section{Hasil Penelitian dan Pembahasan}

\subsection{User Interface}

Gambar 4 dan Gambar 5 merupakan tampilan dari website monitoring yang menampilkan data yang dikirim oleh sensor node. Dalam penelitian yang dilakukan website monitoring ini dibangun dengan menggunakan Framework Codelgniter, PHP dan MySQL.

1. Form tampil semua data

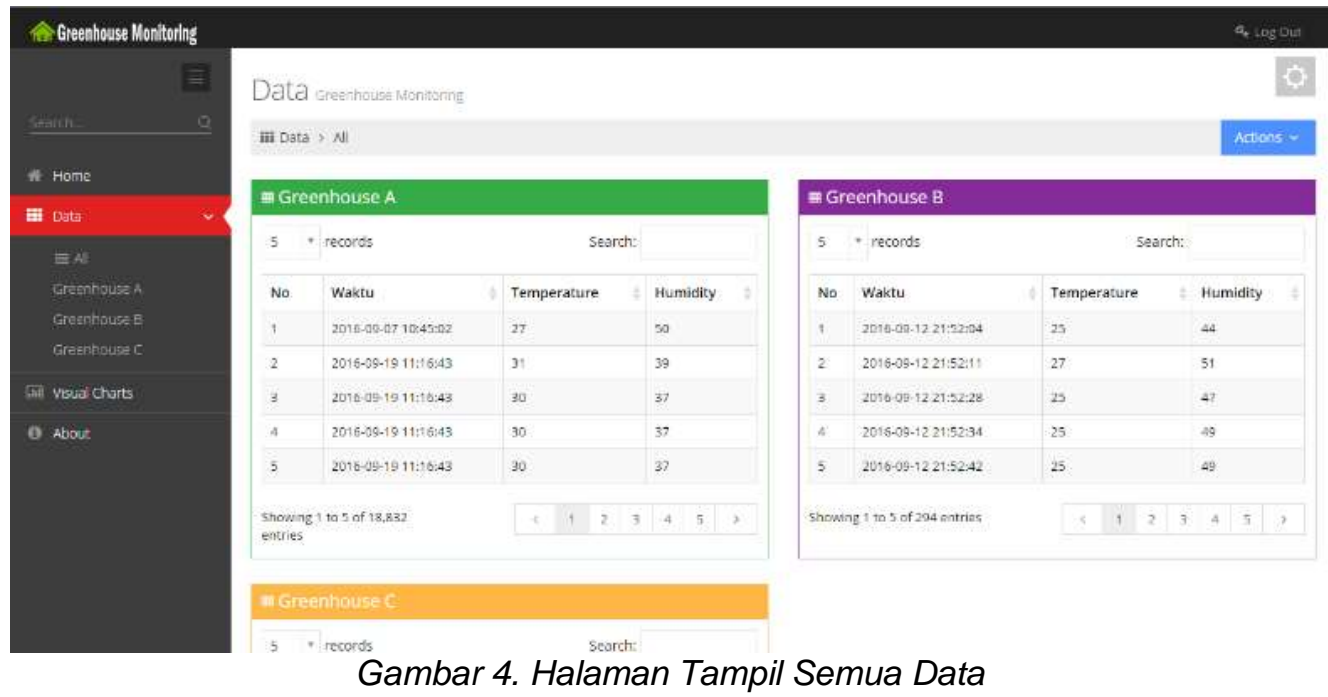

Prototype Sistem Multi-Telemetri Wireless..., Hanum Shirotu Nida, Mahar Faiqurahman, 
2. Form grafik

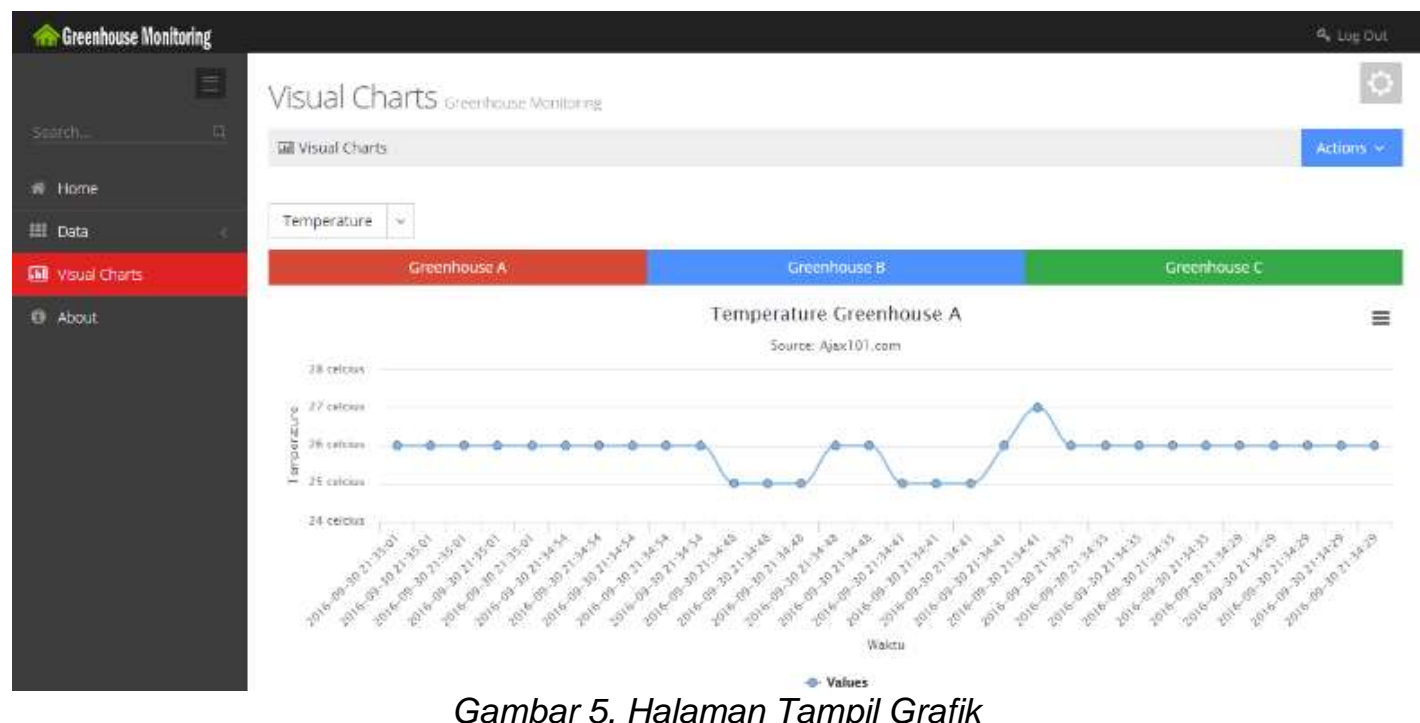

\subsection{Rangkaian Sensor Node}

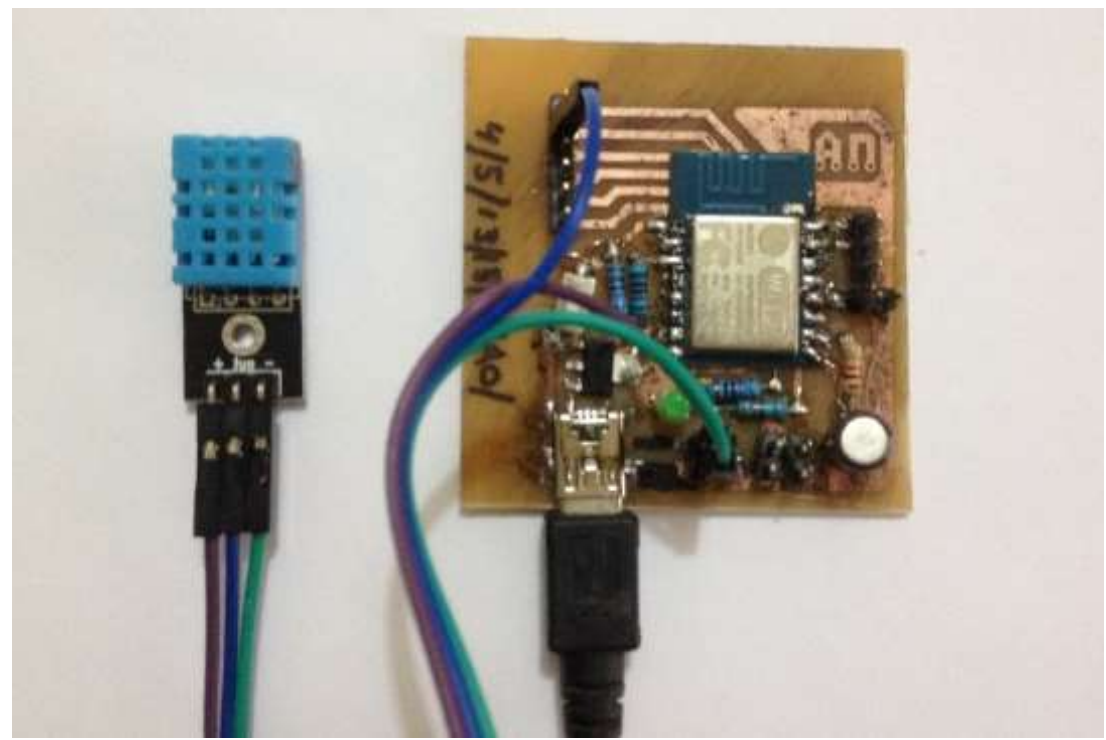

Gambar 6. Rangkaian Sensor Node

Implementasi dari rangkaian sensor node dapat dilihat pada Gambar 6. Rangkaian sensor node ini aktif ketika diberi tegangan 5 Volt, di dalam papan PCB tegangan dibagi menjadi 3.3 Volt dan 5 Volt. Sensor DHT11 memiliki 2 Pin, yaitu VCC, data dan ground. Pin yang digunakan untuk mengambil data sensor adalah Pin data yang disambungkan dengan Pin GPIO pada ESP8266.

\subsection{Pengujian Sensor DHT11}

Pengujian sensor DHT11 dilakukan untuk menguji apakah sensor DHT11 dapat membaca suhu dan kelembaban dengan baik. Pengujian sensor suhu dilakukan dengan membandingkan hasil pengukuran sensor DHT11 dengan thermometer humidity digital HTC-1. Pengujian ini dilakukan di dalam ruangan dengan mengambil sampel data setiap menit.

Hasil pengujian pada sensor DHT11 dapat dilihat pada Gambar 7. Data hasil pengujian tersebut merupakan perbandingan antara data sensor DHT11 dengan pengukur suhu HTC -1, yang didapatkan hasil yang berbeda tiap sensornya. Hasil yang paling rendah kesalahan ukurnya adalah DHT11 A dengan temperature error $0.41{ }^{\circ} \mathrm{C}$ dan humidity error $0.3 \%$, sedangkan 
kesalahan ukur yang paling tinggi adalah $\mathrm{DHT} 11 \mathrm{~B}$ dengan temperature error $2.6^{\circ} \mathrm{C}$ dan humidity error $4.3 \%$. Rata-rata kesalahan ukur suhu adalah $0.92^{\circ} \mathrm{C}$ dan kelembaban adalah $3.1 \%$.

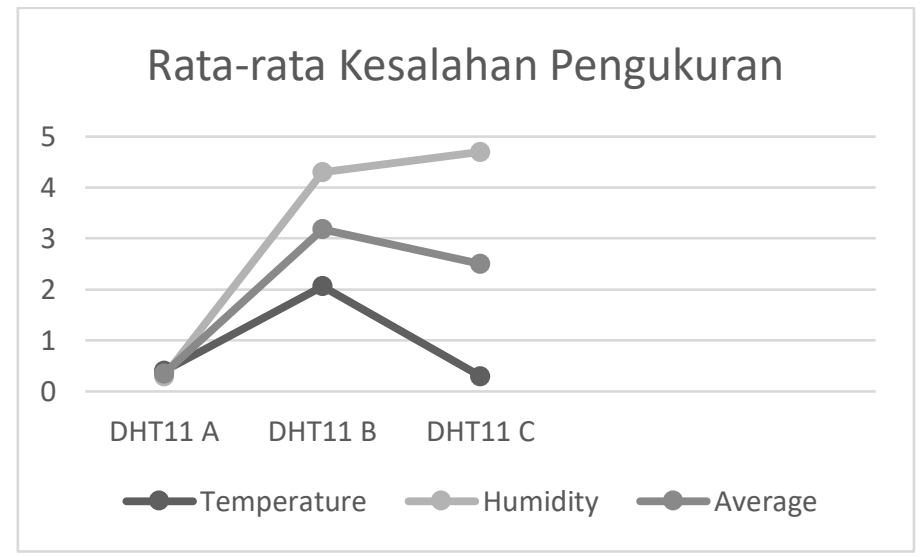

Gambar 7. Rata-rata Kesalahan Ukur Sensor DHT11

\subsection{Pengujian Heap Memory ESP8266}

Pengujian heap memory dilakukan untuk mengetahui kemampuan modul WiFi ESP8266 dalam melakukan proses penyimpanan data. Modul WiFi ESP8266 mempunyai RAM size > 36kB yang digunakan untuk menjalankan program pada modul tersebut, serta digunakan untuk menyimpan data yang diproses oleh mikrokontroler. Parameter pengujian yang digunakan adalah besar array yang berfungsi sebagai buffer data pembacaan sensor. Dalam pengujian dilihat pengaruh besar buffer terhadap heap memory yang ada dalam ESP8266. Pengujian dilakukan dengan memvariasikan ukuran array yang digunakan untuk buffer data dan pengaruhnya terhadap heap memory yang kosong pada ESP8266.

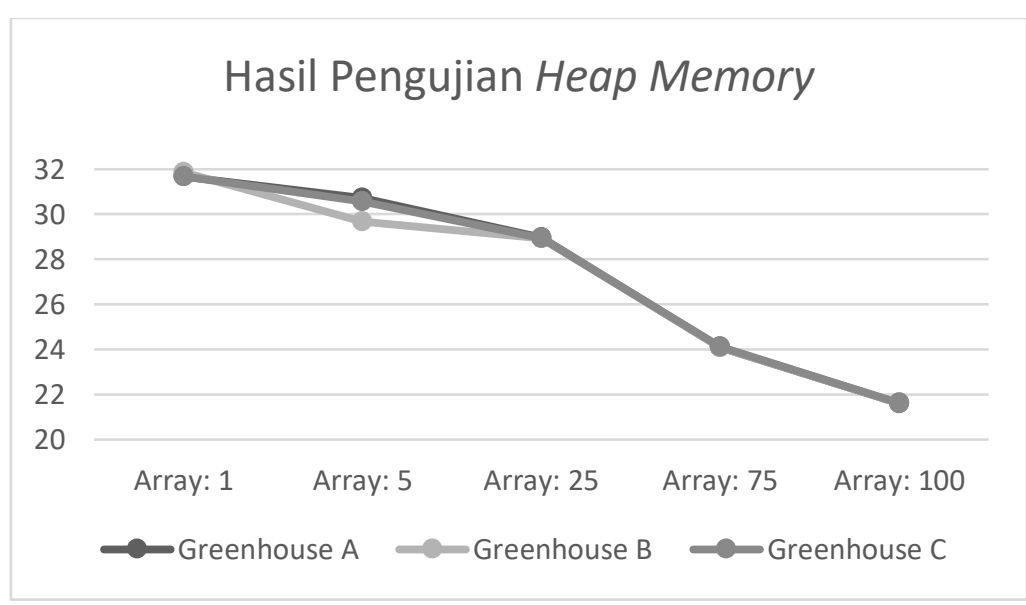

Gambar 8. Hasil Pengujian Heap Memory ESP8266

Gambar 8 menunjukkan hasil pengujian heap memory. Dari hasil pengukuran heap memory pada ESP8266 tersebut dapat dilihat bahwa semakin besar ukuran array yang diinisialisasikan maka akan berpengaruh terhadap heap memory yang tersisa di dalam ESP8266. Dari ketiga pengujian, minimal heap memory yang tersisa di dalam RAM adalah 21612 Bytes yang dapat menampung hingga 100 data. Modul ESP8266 akan error dan reset otomatis ketika heap memory yang tersisa kurang dari nilai tersebut.

\subsection{Pengujian Jarak atau Jangkauan ESP8266}

Pengujian jarak atau jangkauan dilakukan untuk mengetahui seberapa jauh jangkauan modul WiFi ESP8266 dapat melakukan pengiriman data. Parameter yang digunakan adalah jarak antara access point dengan modul WiFi ESP8266. Hasil pengujian dilihat dari seberapa jauh jarak dan pengaruh dengan data pembacaan sensor dapat terkirim atau tidak. Pengujian dilakukan di tempat terbuka tanpa penghalang dinding. 


\begin{tabular}{cccccccc}
\hline \multicolumn{7}{c}{ Tabel 1. Pengujian Jarak ESP8266 } \\
\hline Array & $\begin{array}{c}\text { Jarak } \\
(\mathrm{m})\end{array}$ & \multicolumn{2}{c}{ Greenhouse A } & \multicolumn{2}{c}{ Greenhouse B } & \multicolumn{2}{c}{ Greenhouse C } \\
\cline { 3 - 7 } & Freeheap & Ket & Freeheap & Ket & Freeheap & Ket \\
\hline 5 & 5 & 30296 & Data terkirim & 30712 & Data terkirim & 30328 & $\begin{array}{c}\text { Data } \\
\text { terkirim }\end{array}$ \\
\hline 5 & 10 & 29752 & Data terkirim & 30808 & Data terkirim & 30136 & $\begin{array}{c}\text { Data } \\
\text { terkirim }\end{array}$ \\
\hline 5 & 20 & 29192 & Data terkirim & 30712 & Data terkirim & 30512 & $\begin{array}{c}\text { Data } \\
\text { terkirim }\end{array}$ \\
\hline 5 & 40 & 30680 & Data terkirim & 30712 & Data terkirim & 29944 & $\begin{array}{c}\text { Data } \\
\text { terkirim }\end{array}$ \\
\hline 5 & 50 & 31560 & Data terkirim & 30760 & Data terkirim & 29944 & $\begin{array}{c}\text { Data } \\
\text { terkirim }\end{array}$ \\
\hline 5 & 60 & 30920 & Tidak Stabil & 30808 & Tidak Stabil & 29944 & $\begin{array}{c}\text { Tidak } \\
\text { terkirim }\end{array}$ \\
\hline 5 & 70 & - & $\begin{array}{c}\text { Databil tidak } \\
\text { terkirim }\end{array}$ & - & $\begin{array}{c}\text { Data tidak } \\
\text { terkirim }\end{array}$ & - & $\begin{array}{c}\text { Data } \\
\text { tidak } \\
\text { terkirim }\end{array}$ \\
\hline
\end{tabular}

Hasil dari pengujian jarak dan jangkauan dapat dilihat pada Tabel 1. Pengujian jarak dari ketiga ESP8266 didapatkan hasil untuk jarak 5-50 meter data masih bisa terkirim. Sedangkan pada jarak 60 meter, beberapa data dapat terkirim, dan beberapa data tidak dapat terkirim. Sedangkan lebih dari 60 meter data tidak dapat terkirim sama sekali. Dari hasil pengujian juga dapat dilihat bahwa jarak atau jangkauan sensor node dan server tidak berpengaruh terhadap free heap memory pada ESP8266.

\subsection{Pengujian Data Missing Handling}

Mekanisme data missing handling dilakukan untuk mengatasi agar data tidak hilang ketika server sedang tidak tersedia atau tidak dapat diakses oleh sensor node. Skenario pengujian dilakukan dengan cara sensor node melakukan proses sensing selama 10 menit, kemudian jika server tidak tersedia dan data tidak dapat terkirim maka sensor node akan mencoba mengirim data berulang sebanyak 10 kali. Ketika percobaan pengiriman ke 10 server masih unavailable atau data masih belum terkirim, maka sensor node akan menghapus data sebelumnya dan akan menggantinya dengan data yang baru dengan proses sensing ulang.

Tabel 2 merupakan hasil pengujian data missing handling ketika server tidak tersedia dengan menunjukkan proses yang sedang berjalan dalam server dan sensor node. Adanya mekanisme data missing handling, data hasil pembacaan sensor tidak hilang ketika server sedang tidak tersedia. Data hasil pembacaan sensor tersimpan pada buffer dan akan terkirim ketika server aktif. Data otomatis akan dihapus dan diganti dengan yang baru ketika server masih tidak aktif dalam jangka waktu tertentu (dalam penelitian ini dibuat 10 menit) sehingga ketika server aktif maka data terbaru yang akan dikirim ke server. Hal ini dimaksudkan agar data tidak hilang ketika server unavailable atau sedang tidak dapat diakses oleh sensor node.

Dalam penelitian ini juga dilakukan pengujian terhadap free heap memory ESP8266 dan dari hasil pengujian, dapat dilihat bahwa proses sensor node untuk mencoba terhubung dengan jaringan secara berulang tidak berpengaruh terhadap heap memory ESP8266.

\subsection{Pengujian Kestabilan Jaringan}

Pengujian kestabilan jaringan dilakukan untuk mengetahui pengaruh jaringan terhadap pengiriman data. Parameter pengujian yang digunakan adalah jumlah access point yang sedang berkomunikasi di sekitar access point server dan channel yang digunakan. Dalam pengujian dilihat pengaruh banyaknya access point yang berkomunikasi dengan channel yang sama, dengan usaha sensor node untuk mengirim data ke server (percobaan terhubung ke server dengan jumlah 10 kali percobaan tiap pengiriman data).

Pengujian dilakukan pada jarak 10 meter, besar array 5 dan delay 1000 dengan dua kondisi. Kondisi pertama, yaitu proses pengiriman data dilakukan pada lingkungan yang terdapat kurang dari 10 access point yang sedang berkomunikasi sekitar access point server dan 2 diantaranya menggunakan channel yang sama dengan access point server (channel 11+7).

KINETIK Vol. 2, No. 3, Agustus 2017: 217-226 
Kondisi kedua, yaitu proses pengiriman data dilakukan pada lingkungan yang terdapat lebih dari 10 access point yang sedang berkomunikasi disekitar access point server dan 5 diantaranya menggunakan channel yang sama dengan access point server (channel 11+7). Hasil pengujian kestabilan jaringan dapat dilihat pada Tabel 3.

Dari hasil pengujian kestabilan jaringan didapatkan hasil untuk kondisi satu, yaitu data dari ketiga ESP8266 dapat terkirim dengan satu kali percobaan pengiriman data ke server. Sedangkan pada pengujian kondisi dua pengiriman data tidak stabil dan ada yang tidak terkirim. Dari hasil pengujian dapat dilihat bahwa semakin banyak jumlah access point yang sedang berkomunikasi sekitar access point server dengan menggunakan channel yang sama maka akan berpengaruh terhadap kestabilan pengiriman data atau koneksi sensor node dengan server.

Tabel 2. Pengujian Data Missing Handling Ketika Server Unavailable

\begin{tabular}{cccc}
\hline Menit ke & Server & Sensor node & Free heap \\
\hline 1 & Available & Proses sensing & 30448 \\
\hline 10 & Available & $\begin{array}{c}\text { Mengirim data } \\
\text { (Data terkirim) }\end{array}$ & 30448 \\
\hline 11 & Available & $\begin{array}{c}\text { Proses sensing } \\
\text { (Data tidak terkirim) }\end{array}$ & 30256 \\
\hline 20 & Unavailable & $\begin{array}{c}\text { Mengirim data } \\
\text { (Dy to connect server 1 }\end{array}$ & 30880 \\
\hline 21 & Unavailable & Tryb & 30880 \\
\hline 22 & Unavailable & Try to connect server 2 & 30880 \\
\hline 23 & Unavailable & Try to connect server 3 & 30880 \\
\hline 24 & Unavailable & Try to connect server 4 & 30880 \\
\hline 25 & Unavailable & Try to connect server 5 & 30880 \\
\hline 26 & Unavailable & Try to connect server 6 & 30880 \\
\hline 27 & Unavailable & Try to connect server 7 & 30880 \\
\hline 28 & Unavailable & Try to connect server 8 & 30880 \\
\hline 29 & Unavailable & Try to connect server 9 & 30880 \\
\hline 30 & Unavailable & Try to connect server 10 & 31088 \\
\hline 31 & Unavailable & Proses sensing & 31088 \\
\hline 40 & Unavailable & Mengirim data \\
& (Data tidak terkirim) & 31088 \\
\hline 40 & Unavailable & Try to connect server 1 & 31088 \\
\hline 41 & Unavailable & Try to connect server 2 & 31088 \\
\hline 42 & Unavailable & Try to connect server 3 & 31088 \\
\hline 43 & Available & $\begin{array}{c}\text { Mengirim data } \\
\text { (Data terkirim) }\end{array}$ & 30280 \\
\hline 44 & Available & Proses sensing & \\
\hline
\end{tabular}

Tabel 3. Pengujian Kestabilan Jaringan Jumlah Percobaan Sensor Node Terhubung ke Server

\begin{tabular}{ccccccc}
\hline \multirow{2}{*}{$\begin{array}{c}\text { Pengiriman } \\
\text { Data }\end{array}$} & \multicolumn{2}{c}{ ESP8266 A } & \multicolumn{2}{c}{ ESP8266 B } & \multicolumn{2}{c}{ ESP8266 C } \\
\cline { 2 - 8 } & Kondisi 1 & Kondisi 2 & Kondisi 1 & Kondisi 2 & Kondisi 1 & Kondisi 2 \\
\hline Data 1 & 1 & 1 & 1 & 10 & 3 & 5 \\
\hline Data 2 & 1 & 4 & 1 & 10 & 1 & 1 \\
\hline Data 3 & 1 & 1 & 4 & 10 & 1 & 1 \\
\hline Data 4 & 1 & 10 & 1 & 10 & 1 & 1 \\
\hline Data 5 & 1 & 10 & 1 & 10 & 1 & 5 \\
\hline
\end{tabular}

\section{Kesimpulan}

Berdasarkan proses observasi, analisis dan implementasi pada tugas akhir tentang sistem multi-telemetri wireless untuk mengukur suhu udara, penulis membuat beberapa kesimpulan, yaitu:

1. Sistem multi-telemetri wireless untuk mengukur suhu udara dirancang dengan menggunakan sensor suhu DHT11, modul WiFi ESP8266 sebagai media komunikasi dan HTTP protokol untuk protokol komunikasinya.

2. Aplikasi berbasis web dirancang dengan menggunakan Codelgniter, PHP dan MySQL untuk menampilkan data hasil pembacaan sensor yang dikirim oleh sensor node.

Prototype Sistem Multi-Telemetri Wireless..., Hanum Shirotu Nida, Mahar Faiqurahman, 
3. Dari hasil pengujian didapatkan bahwa sensor $\mathrm{DHT} 11$ memiliki rata-rata kesalahan ukur suhu adalah $0.92{ }^{\circ} \mathrm{C}$ dan kelembaban adalah 3.1\%. Sedangkan modul WiFi ESP8266 mampu menyimpan dan mengirim buffer hingga 100 data dan dapat melakukan pengiriman dalam jangkauan 50 meter. Pengujian data missing handling memanfaatkan buffer untuk menyimpan data selama server sedang tidak dapat diakses oleh sensor node untuk mengurangi risiko hilangnya data. Kestabilan pengiriman data atau koneksi sensor node dengan server dipengaruhi oleh jumlah access point yang sedang berkomunikasi sekitar access point server dengan menggunakan channel yang sama. Dalam hal ini berjalannya sistem bergantung pada kestabilan jaringan, rangkaian sensor node dan hubungan antara sensor node dan server.

\section{Referensi}

[1] H. Zhang, H. Xue, "Design of Greenhouse Environmental Parameters Prediction System," in International Conference on Computer and Computing Technologies in Agriculture. Springer, 2010, Pp. 502-507.

[2] D. Risqiwati, "Rancang Bangun Sistem Monitoring Listrik Prabayar dengan Menggunakan Arduino Uno," KINETIK, Vol. 1, No. 2, Pp. 47-54, 2016.

[3] A. Maarif, "System Monitoring And Controlling Water Nutrition aquaponics Using Arduino Uno Based Web Server," KINETIK, Vol. 1, No. 1, 2016.

[4] K. . Bhoomika, K. N. Muralidhara, "Secured Smart Healthcare Monitoring System Based on IOT," International Journal on Recent and Innovation Trends in Computing and Communication, Vol. 3, No. 7, 2015.

[5] D. Chaudhary, S. Nayse, "Application of wireless sensor networks for greenhouse parameter control in precision agriculture," International Journal of Wireless \& Mobile Networks (IJWMN), Vol. 3, No. 1, Pp. 140-149, 2011.

[6] M. S. Munir, "Rancangan Smart Greenhouse dengan Teknologi Mobile untuk Efisiensi Tenaga, Biaya dan Waktu dalam Pengelolaan Tanaman," Universitas Pembangunan Nasional Veteran, 2010.

[7] S. Sawidin, O. Melo, T. Marsela, "Monitoring Kontrol Greenhouse untuk Budidaya Tanaman Bunga Krisan dengan LabView," Jurnal Nasional Teknik Elektro dan Teknik Informatika, Vol. 4, No. 4, 2015.

[8] I. Pambudi, Y. Nugraha, M. Djamal, "Sistem Telemetri Pemantau Gempa Menggunakan Jaringan GSM," Jurnal Otomasi, Kontrol, dan Instrumentasi ITB, Vol. 4, No. 1, Pp. 47, 2012.

[9] M. Wastharini, D. Arseno, I. Hidayat, "Perancangan dan Implementasi Sistem Telemetri Suhu Ruangan Berbasis Mikrokontroler," Universitas Telkom Bandung, 2010.

[10] H. Susanto, R. Pramana, "Perancangan Sistem Telemetri Wireless untuk Mengukur Suhu dan Kelembaban Berbasis Arduino Uno R3 ATmega328p dan XBee Pro," Universitas Maritim Raja Ali Tanjung Pinang, 2013. 